マイクロ RNA の細胞外放出の鍵を握る小胞 : エクソゾーム

\author{
石橋 宰 ${ }^{1}$ 竹下 俊行 $^{2}$ 瀧澤 俊広 ${ }^{1}$ \\ ${ }^{1}$ 日本医科大学大学院医学研究科分子解剖学 \\ ${ }^{2}$ 日本医科大学大学院医学研究科女性生殖発達病態学
}

\title{
A Tiny Vesicle Called Exosome Is a Key Cellular Compartment for MicroRNA Secretion from Cells
}

Osamu Ishibashi ${ }^{1}$, Toshiyuki Takeshita $^{2}$ and Toshihiro Takizawa ${ }^{1}$

${ }^{1}$ Department of Molecular Medicine and Anatomy, Graduate School of Medicine, Nippon Medical School

${ }^{2}$ Division of Reproductive Medicine, Perinatology and Gynecologic Oncology, Graduate School of Medicine, Nippon Medical School
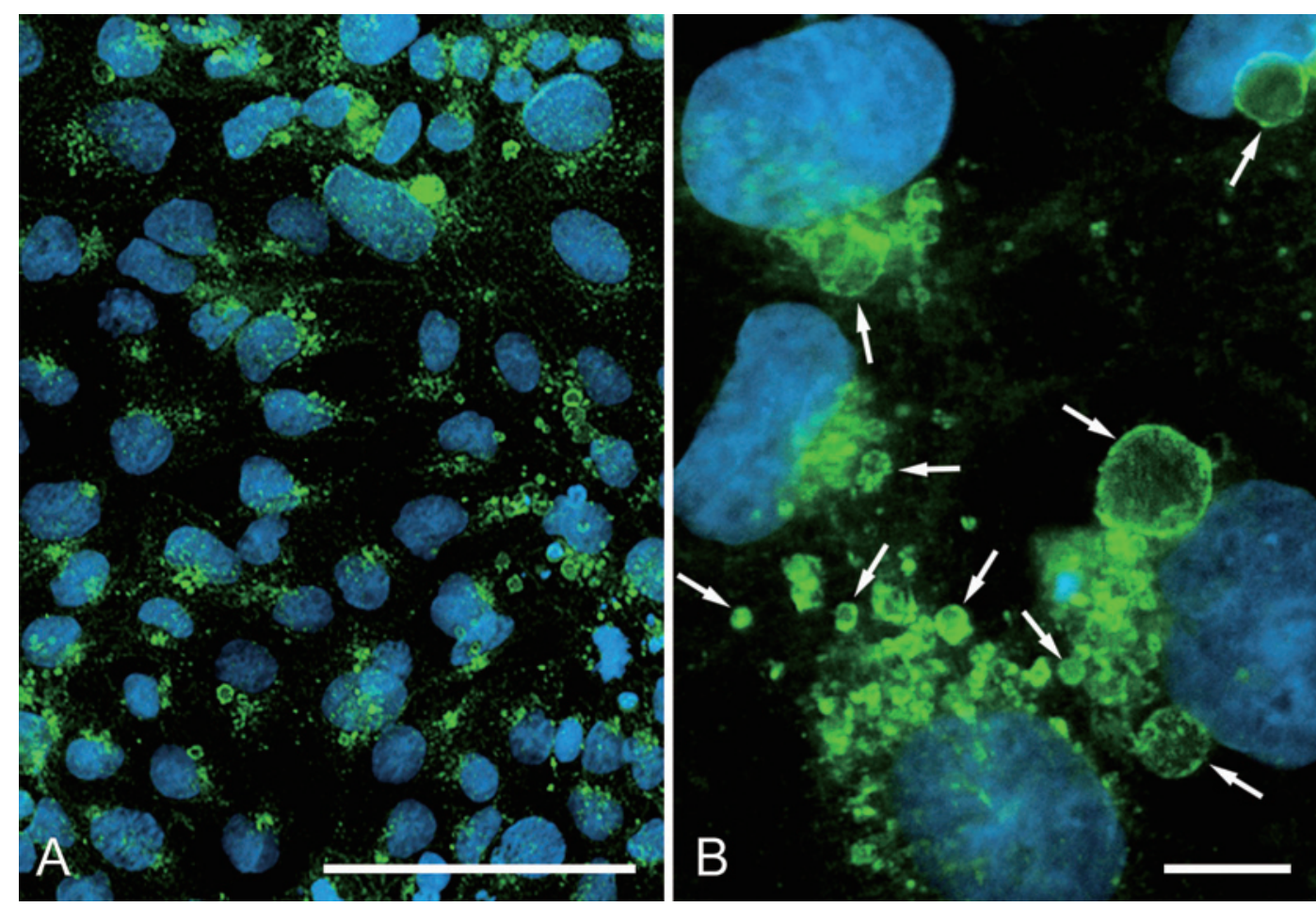

図 1

エクソゾーム (exosome) は，細胞から分泌される小胞 である. エクソゾームは, 細胞内の多胞体 (multivesicular body）に由来し，多胞体が細胞膜と融合することにより 内部の小胞（エクソゾーム）が細胞外に放出される. マイ クロ RNA は約 22 塩基から成る 1 本鎖の非コード RNA で あり, 転写後の遺伝子発現調節に関与する機能性 RNA と

図1 BeWo 細胞における CD63 の免疫細胞化学.

BeWo 細胞をパラフォルムアルデヒドで固定後, 一次抗体 に抗 CD63 抗体, 二次抗体に Alexa Fluor 488 標識抗体, DAPIによる核染色（青）を同時に行い，オリンパス社製
して注目を集めている。 ヒト胎盤では, 絨毛栄養膜で胎盤 特異的マイクロ RNA が産生され，エクソゾームを介して 母体血液中に放出される ${ }^{1}$. 胎盤栄養膜のモデルである細 胞株 BeWo において, CD63 を指標としてエクソゾームお よび多胞体を可視化した.

蛍光顕微鏡 BX60 で撮影した. A : BeWo 細胞の低倍像. B : 高倍像. 細胞内に CD63 (内因性 CD63; 緑) の局在 を示す大小の小胞状の蛍光シグナルが観察される (矢印). スケールバー $\mathbf{A} ; 100 \mu \mathrm{m}, \mathbf{B} ; 10 \mu \mathrm{m}$.

連絡先 : 瀧澤俊広 $\overline{1} 113-8602$ 東京都文京区千駄木 1-1-5 日本医科大学解剖学講座（分子解剖学）

E-mail: t-takizawa@nms.ac.jp

Journal Website (http://www.nms.ac.jp/jmanms/) 


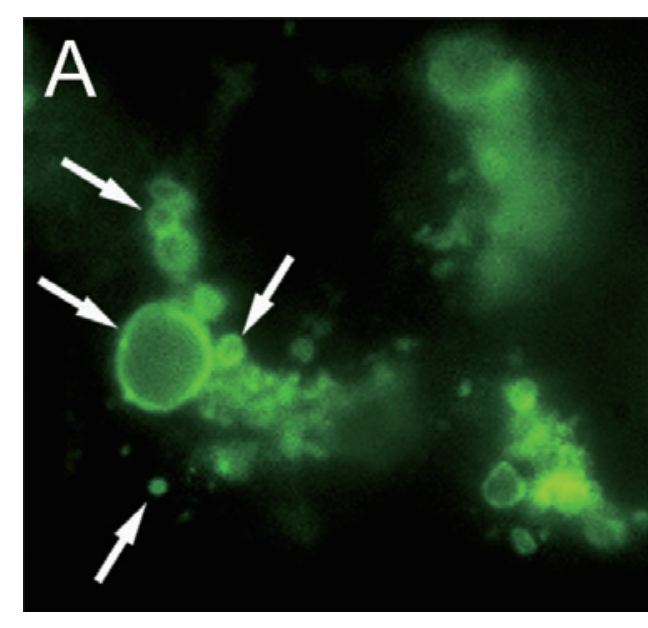

\section{B}
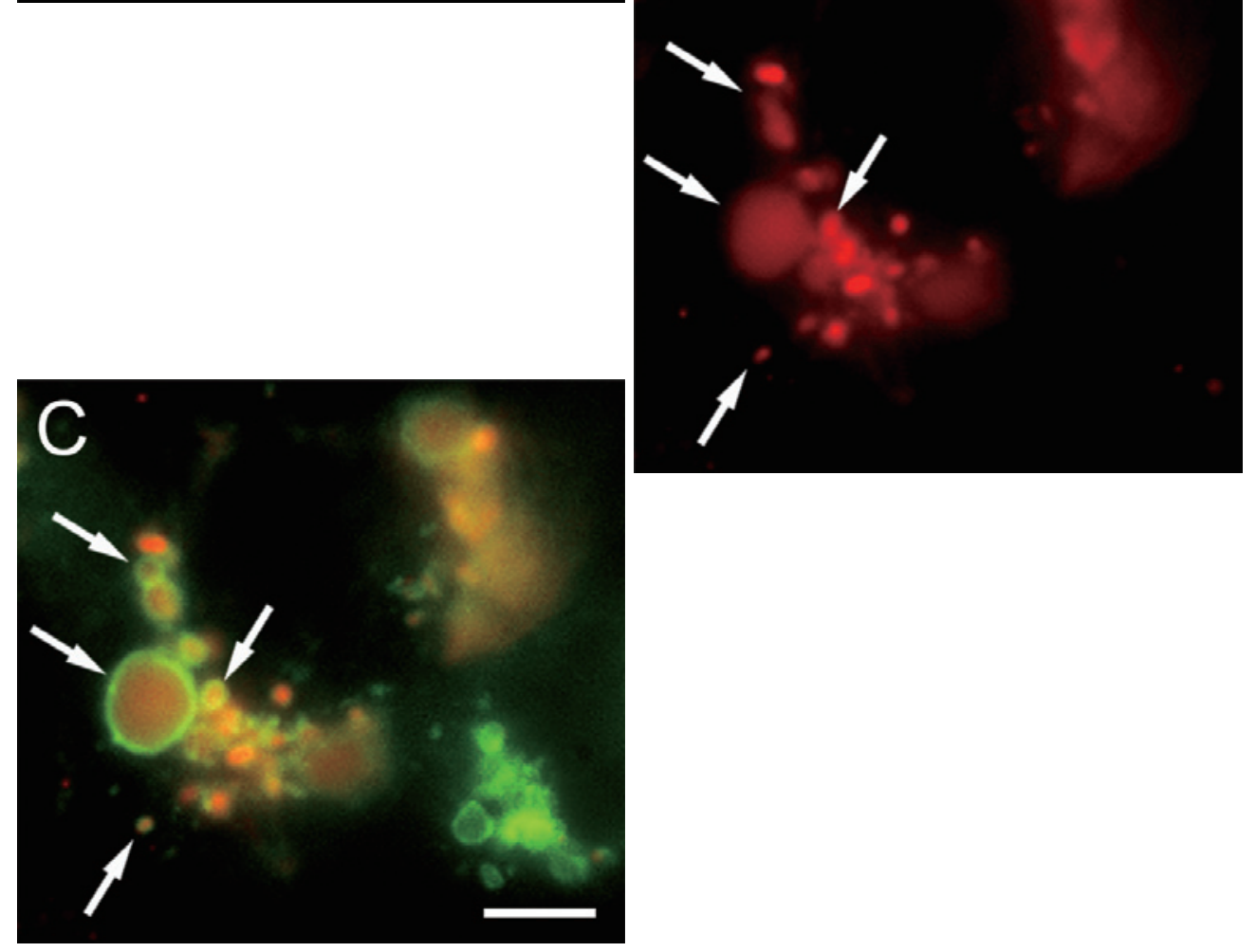

図 2

戝2 EGFP-CD63 発現 BeWo 細胞を用いたバイオイメー ジング解析.

多胞体のマーカーであるCD63に enhanced green fluorescent protein (EGFP) を結合した EGFP-CD63 発 現 BeWo 細胞を作製 1,2, Alexa Fluor 594 標識したマイク ロ RNA (MIRLET7B ; 赤) を導入し，オリンパス社製蛍 光顕微鏡 IX71-TIRFM-SP で撮影した. A：EGFP-CD63

\section{文 献}

1. Luo S-S, Ishibashi O, Ishikawa G, Ishikawa T, Katayama A, Mishima T, Takizawa T, Shigihara T, Goto T, Izumi A, Ohkuchi A, Matsubara S, Takeshita T, Takizawa $\mathrm{T}$ : Human villous
の発現を示す蛍光像 (緑). 図 1 の内因性 CD63 と同様に, 小胞状の蛍光シグナルが観察される. $\mathrm{B}$ ：細胞内に取り込 まれたマイクロ RNAの局在を示す蛍光像 (赤). C：A と B の合成像. EGFP-CD63 陽性の小胞様構造 (緑)に取り 込まれた MIRLET7B（赤）が観察される（矢印）。スケー ルバー $10 \mu \mathrm{m}$.

trophoblasts express and secrete placenta-specific microRNAs into maternal circulation via exosomes. Biol Reprod 2009; 81 : 717-729.

2. Amano T, Furuno T, Hirashima N, Ohyama N, Nakanishi M: Dynamics of intracellular granules with CD63-GFP in rat basophilic leukemia cells. J Biochem 2001; 129: 739-744. 